\title{
sciendo
}

\section{The Role of InteractiveTeaching Strategies in Business Education: Challenges for the 21st Century}

\author{
Eleonora Gabriela CONTU \\ University of Bucharest, Bucharest, Romania \\ Email address: eleonora.contu@faa.unibuc.ro
}

PICBE $\mid 125$

\begin{abstract}
In contemporary context, broad innovation in the education domain through the use and capitalization of interactive teaching strategies in the educational-training process can only help improve the teaching and training of younger generations in order for them to adapt and achieve performance in line with labour market challenges. The role of teachers as tutors that shape destinies towards performance and success is essential in a modern and complex society. Worldwide, training intelligent and fascinating young people is a challenge today. Success arises from the ability of teachers who have to form younger generations not to memorize and repeat information, but to build a space that is adequate for a harmonious development of excellent people who guide themselves in life according to moral values and principles. The study rely on a qualitative research, conducted on a sample of convenience, consisting of 56 respondents (students at a Business School from Bucharest, Romania). The research question raised at this point is: What is the role of interactive teaching in the educational-training process? The purposes of this study are: 1). to highlight the importance of using interactive teaching methods in business education; 2). to present the main aspects for achieving an effective didactic communication; 3). to highlight the importance of education as a means of investing in human capital; 4). to emphasize the way in which New Information and Communication Technologies influence the educational-training process; 5). to present the qualitative research findings.It was found that interactive teaching has a great importance for the whole interactive teaching process. The ideas mentioned by the young respondents surprisingly render the issue of digitization and its effects on the educational-training process. The topic of this paper is interesting and its original content provides information for further researches in this area.
\end{abstract}

Keywords: business education, teaching methods, intellectual capital, interactive teaching, higher education.

\section{Introduction}

In this era of technology, the development of critical thinking and creativity succeeds in giving young generations self-confidence, power to face the failures of life and an excellent education.

The study provides interesting answers according to an interview guide that was used in order to obtain relevant ideas regarding the importance of using interactive teaching in the educational-training process. Also, starting from the importance of digital in the field of education both the profile of the teacher and that of the student of the future were designed according to the main characteristics named by the students.

New Information and Communication Technologies (NICT) produce value, relational and procedural changes that shouldn't be neglected. Nowadays, when we relate to this new field, the way to do education requires both trainers and trainees with certain skills (Bratianu \& Vatamanescu, 2017).

It is important to mention that the technology could be strong and might be used "for a good course to enhance the world" (Sorensen, 2007). So, "global flows of people, ideas 
knowledge, messages, technologies and capital" are growing faster and are continuously changing (Marginson, 2010). Also, a very important idea is that "in the face of global economic competitiveness the idea of innovating has found favour among governments, industry and academia" (Chaharbaghi and Newman, 1996).

Digitization has had a spectacular momentum, which has forced major changes in all areas of activity. The border between traditional and modern has long been crossed. Now, we are all involved in a new environment (that of digitization), which forces us to face challenges that emerge constantly.

We ask ourselves: How will things evolve? What future does digitization offer us? How far will things evolve? How can be used digitization to increase the intellectual capital (Bratianu, 2018; Bratianu \& Bejinaru, 2017) of a university?

What is important to know? Well, let us rely on certainties, real things, based on solid values and principles of life, to be flexible, to develop our ability to make projections for the future. In other words, we have to understand that there is more than one way to achieve our own goal worth achieving. It is important to reopen the agenda of the mind, and trying to find answers to questions such as: Am I doing the right thing? What do I have to do today? What do I have to accomplish?

\section{Literature review}

\section{Highlighted the importance of using interactive teaching methods in business education}

Nowadays, teachers should use more and more different interactive teaching methods in order to obtain a complete educational-training process. It is also important, if we think about business education, to be aware of the challenges that arise in the business environment, and to think how to educate young generations to face this challenge when it is necessary to put into practice the knowledge acquired.

In this context, it is important to imply students in developing portfolios, case studies, reflective journals or projects (Contu, 2017). Also, the use of heuristicconversational strategy in the debate can bring for the students the possibility to think creatively (Contu, 2017).

It is important to mention that "in online learning" the Internet provides unique opportunities being possible to replace the traditional classroom teaching with a place that "provides 'on demand' education at the convenience of the students" (Sit et.all , 2005).

\section{Presenting the main aspects for achieving an effective didactic communication}

In general, the study of communication refers to the following aspects: "knowledge", "understanding", "ability" (Agabrian, 2008). Therefore, if "in the past, the art of effective communication (the ability to express one's own ideas and opinions and their understanding by other people) was thought to be based solely on the correct use of language", it is currently observed that "all communication involves creation and exchange of meanings "(Agabrian, 2008).

It is undeniable that "communication is a non-recurring and irreversible process; every communication experience is unique and two communication experiences cannot be identical"(Pânişoară, 2008). Also, the same author mentions that "communication is an open system, influenced by many factors", and the existence of barriers in the 
communication process cannot be neglected (Pânişoară, 2008). There are five "barriers" that appear in the communication process such as "barriers in sending the message, barriers in receiving it, barriers in understanding, barriers in acceptance, and barriers in action" (Pânişoară, 2008). It is important to mention that fellings of interest may be very usefull for learning process such us fear and anxiety that can put few barriers in learning process, while positive fellings of interest may be very important for learning (Kolb and Kolb, 2005). Augustsson (2010) considers that "emotional experiences" are essential and are very often associated with the reflexivity which people use in order to relate their own emotions (Augustsson, 2010).

Therefore, in order to be effective, communication, like any human activity, must be conducted according to norms and values and well-structured theoretical principles (Agabrian, 2008).

\section{Highlighting the importance of education as a mean of investing in human capital}

Through experience and the ability to integrate their own knowledge using their own judgment, people contribute to the movement of the whole functioning mechanism of an organization (Mayo, 2001). So, the importance of individual knowledge (that "represents all the knowledge with any individual employee") is very important at the level of an organization (Brătianu et all, 2011). Similarly, in the educational context, both students and teachers, when communicating for the successful realization of the instructive-educational process bring along their own values and norms, a certain conduct. So, investing in human capital should be an essential condition for achieving progress.

The idea that "information is power" and an important task is to put the "education and training" at the first place in an individual life, and also on the first level of an organization and each society must be carefully analysed (Iatagan, 2012). Moreover, let us not forget that "the real treasure of a country is education" (Iatagan, 2012).

However, these aspects would not be achieved unless the most important "actors" of education were involved: students / pupils. There are many factors that influence their innovative behaviour and they should not be neglected, because taking into account these, the effectiveness of the whole educational-educational process can be complete. Henceforth, the teacher intervenes, with an important role in education. The two, the student / pupil and the teacher, are entities that cannot be separated in this "specific socialhuman action" - education.

In literature review several factors are listed that influence students' approaches to learning (Baeten et all, 2010). As a result of 93 articles retrieved from literature review, these authors consider several encouraging and discouraging factors, namely:

-"contextual factors": "characteristics of teaching methods", "feedback", "teacher ersonality", "time spent on student-centred teaching" and so on;

-"perceived contextual factors": teaching, independent study, learning activities assessment and so on;

-"student factor": initial approach to learning, age, personality, social style, emotions and so on.

It is important to mention that several of these factors influence students' behaviour and approaches to learning. 
In the literature review is presented "The Jackson model" (1982) (Vrontis, Thrassou and Melanthiou, 2007). This model proposes that "a student goes through three stages prior to making a choice" (Vrontis, Thrassou and Melanthiou, 2007):

-The first stage is "the preference stage": in this stage student's familiy background social context will influence his/her preferences.

- The second stage consists in sending the student to exclude some institutions from his/her list.

- At the end a rating scheme that leads to final choice is made.

\section{Methodology}

In order to obtain empirical information a qualitative research based on a questionnaire was used. A sample of convenience consisted of 56 students from the Faculty of Administration and Business, University of Bucharest, Bucharest (students in the last year of bachelor programme). The data collection tool was a semi-constructed questionnaire, comprising 10 questions. Focus-groups consisting of 14 students were made during the seminar class in December 2018. The questionnaire contained a large number of open questions.

The scope of the research consists in emphasizing the role of interactive teaching in training-educational process, and identifying the student's profile and teacher's profile in the future. According to key questions the objectives of the research are: styles;

$\mathrm{O}_{1}$ : Identifying the teachers' personality traits who apply different educational

$\mathrm{O}_{2}$ : Identifying the main features of interactive teaching in the context of NICT;

$\mathrm{O}_{3}$ : Identifying the main advantages/disadvantages of interactive teaching;

$\mathrm{O}_{4}$ : Shaping the student's profile;

Os: Identifying the student's role in the context of interactive teaching.

According to a personal research made in 2017 respondents (students at the same Business School, in Romania) identified some principles of learning. There were outlined few of them in the context of using interactive teaching methods by teachers, such as: "attention", "desire to learn", "effective communication" (Contu, 2017).

Also, according to a personal research made in 2015 the interviewees were asked to identify what are the main advantages / disadvantages of using NICT in education (Baban, 2015). Students answers outlined both advantages and disavantages, for example: advantages - "documentation is faster", "creative learning", the process of teaching/learning is flexible, "fast and efficient communication" and so on; disadvantages "the possibility of obtaining erroneous information", "not all people have access to the Internet", "students are tempted not to take notes during courses" and so on (Baban, 2015).

\section{Results and discussions}

In order to achieve a qualitative research, four groups (fourteen students in each group) were formed. The discussion began according to an interview guide.

The interview questions were the following:

1. Do you think that interactive teaching helps organize the educational process, while stimulating individual participation? 
2. Do you think that interactive teaching determines the student to become responsible for achieving the proposed goals with maximum efficiency?

3. Do you think interactive teaching helps clarify the purpose of creative learning?

4. In the context of new information and communication technologies, do you think interactive teaching plays an important role?

5. How do you believe effective interactive teaching can be achieved in the context of new

PICBE $\mid 129$ information and communication technologies?

6.In your opinion, what are the main trends of the instructive-educational process in the context of innovative technologies?

7. Do you think that the development of students' creative potential depends on the creative conduct of the teacher? Justify your answer.

8. Didactic communication plays a major role in the achievement of the educational process. In your opinion, what are the main characteristics of the teacher that help deliver effective teaching? How about those of the student?

9.In your opinion, what personality traits does a teacher practicing an authoritative educational style have? How about those of a teacher practicing an emotional educational style? Or flexible?

10.Education is the main component of human capital. Complete the following ideas:

Education needs to help in (...).

Education determines (...) .

Education and training are (...).

Respondents answered to question number one and listed some features of the interactive teaching:

-Interactive teaching helps organize the educational process, while stimulating individual participation, because: introverted people can feel a higher degree of comfort, so students are encouraged to better "express their thoughts, ideas, feelings"; "it stimulates each participant to communicate and express his/her own idea"; " this method attracts students to participate in a dialogue in a pleasant way", a constructive dialogue that leads students to learn in a more pleasant way; it contributes to personal development, stimulating students' ability to speak in public on various topics; students can communicate more easily; a pleasant environment is created, students become more relaxed, gaining selfconfidence; attention is captured; "we don't get bored and we put our minds to use"; the student becomes involved; "This kind of education can be a challenging one, one on one, folded on each student's wishes for development"; students' opinions are heard and debated. One respondent stated, "Yes, it helps, in a certain extent, but I don't think it stimulates individual participations".

The relevant answers to question number two are listed as it fallows:

- "Interactive teaching determines the student to become more responsible, more creative, he develops his inner side, he becomes more self-conscious of his own opinions, thus succeeding to achieve his objectives with maximum efficiency"; "Yes, because being aware of something means "knowing", and speaking means "knowing"- these are the basic rules in fulfilling the proposed objectives; "The student will want to achieve his/her goals with maximum efficiency as long as there is "a bridge between the teacher and the student". However, there were also some negative answers: "Not necessarily because it depends on the interest of each student if he/she wants to get involved and if he/she is interested in the 
topic"; "Yes, but not always, because not all students are really interested in the topics addressed"; "Sometimes yes, but it depends on the student's interest in the information received".

Respondents answered to question number three that interactive teaching: "develops creativity and helps to express it"; "can clarify the purpose of creative learning because it is a way to put the learned theory into practice"; "supports and develops creative learning". Numerous affirmative responses have been noted, including the following: "Yes, as long as teaching is clear and understandable for everybody"; "Yes. In this way, you can see how fun it is to use your creativity, but also what spectacular ideas can arise from this process"; "Yes, because when interactive teaching is used one can understand and assimilate information more easily and ideas emerge spontaneously"; "It certainly helps. By talking freely about a proposed theme, the information received is assimilated differently compared to the actual listening of a monologue, at which point the student no longer pays attention. Effective engagement "forces him to pay attention". There was also a negative answer, and a simple "I don't know".

According to question number four, respondents relevant answers were the following: "Of course, with the help of new technologies, interactive teaching is much simpler and more complex"; "Yes, because interactive teaching is also relatively new and can be perfectly combined with new information and communication technologies"; "Yes, because technology is a good advantage to get the student's attention"; "Yes, I think interactive teaching is effective in the context of new information and communication technologies because it enhances the student's creativity, which is the most important human value when we refer to technology"; "New technologies don't have to take hold of the teaching / learning process. A teacher's explanations can never be compared to a certain technology, which should only help to a small percentage (about 20\%)". There were also two negative answers.

According to question number five most respondents surveyed said that effective teaching can be achieved through interactive games, teaching by giving examples from everyday life, keeping a constant feedback with the students, introducing educational videos, and using PowerPoint presentations accompanied by many images and actual examples.

According to the answers obtained to question number six respondents listed some trends of the educational process in the context of innovative technologies, among which the following are mentioned: easy learning, pleasant environment, increasing students' interest in knowledge, digital presentations, developing the purpose of creative learning, stimulating student / pupil involvement. An important idea was mentioned: "The tendency to keep up with progress".

According to the answers obtained to question number seven relevant opinions in the debate were selected, such as:

-Affirmative opinions: "It is certain that a student's creativity cannot be expressed, perhaps not even understood by a teacher who does not consider creativity an important element in the learning process"; "Yes, a student's creativity can be influenced by the teacher's attitude, because the latter is like a mentor or an example to follow for the student"; "Yes, creativity depends on how much the teacher proposes to teach the student, but also on how much the student can learn, namely what he "harvested" from the teacher. 
-Negative opinions: "No, because not all students are open to novelty"; "No. I believe that each person has his own intellectual and creative level".

-Another interesting idea was: "I don't think that this definitely influences the development of creative potential, but it certainly stimulates it".

The analysis of the answers to question number eight outlined the following characteristics both teachers' and students that help to obtain an efficient didactic communication. These are the following:

-Teachers characteristics: good teacher, understanding, flexible, passionate, pleasant voice, excellent communication skills, creativity, patient, good sense of humour, good observer, charismatic, serious, good educational taste, indulgent, tolerant, confident, sincere, devoted, good orator, calm, optimistic thinking, resourceful, gentle, demanding when the case, empathic, innovative, pragmatic, concise, clear, thorough, precise, receptive, informed, visionary, good listener, attentive, relaxed, friendly, simple.

-Students' characteristics: communicative, obedient, calm, attentive, responsible, persevering, confident, patient, respectful, serious, involved, receptive, positive energy, diligent, courageous in supporting his/her ideas, creative, willing to learn, with a developed sense of humour, captivated - interested in the subject.

The analysis of the answers to question number nine outlined the following teachers' characteristics who apply different educational teaching styles. These are the following:

-Authoritarian style: He/She is harsh, strict, doesn't smile, austere, strong personality, intelligent, constructivist, serious, sure of him/herself, concise and to the point, fair, unforgiving, imposing, sad, punctual, firm, non-empathic, he/she does not accept others 'opinions, imperative in tone.

-Emotional style: He/She is harsh, strict, doesn't smile, austere, strong personality, intelligent, constructivist, serious, sure of him/herself, concise and to the point, fair, unforgiving, imposing, sad, punctual, firm, non-empathic, he/she does not accept others 'opinions, imperative in tone.

-Flexible style: He/ She is interactive, self-controlled, pleasant, kind, demanding only when needed, involved, with a sense of humour, patient, developed communication skills, adaptable, persevering, perfect, balanced, communicative, tolerant, relaxed., optimistic, understanding, sociable, very creative, dynamic, passionate.

According to the answers obtained to question number ten the following ideas are listed:

-Education must help: individual training, shaping personality, intellect and thinking development, training professionals and respectful people, the formation of a strong character, the human and emotional development of the student, the personal development of the pupil / student, the development of personality and trust, evolution.

-Education determines: the formation of a society, people's level of training, creativity, self-confidence, the road a person will follow, behaviour, actions, desires, the student's / pupil's needs, building a student's successful future, a person's behaviour, building the future, integrating into society, a better approach to life, learning.

-Education and professional training are: the foundation of tomorrow's society, essential for the student when starting a career, essential to the destiny of a person, strictly 
necessary for success, extraordinarily important, the two keys of the future, important in finding a job, education and professional training!!!

\section{Conclusion}

This paper presents a qualitative research whose scope is to enhance the importance of using interactive teaching in the context of digitization. Also, the ideas presented above reflect the importance of interactive teaching in this new environment, that of digital.

In order to obtain relevant answers several interesting questions were address to a number of 56 persons (students at a Business School in the third year of study). According to ten questions (the interviewed guide) relevant answers regarding the role of interactive teaching in the educational-training process have been obtained.

Their answers were interesting and put in evidence ideas regarding the role of interative teaching for the whole interactive- teaching process. These are the following:

-the efficiency and role of interactive teaching in the context of innovative technologies;

-trends of the educational-training process in the context of innovative technologies;

-highlighting competences of the student and the teacher of the future, starting from the importance of digital in academic life.

In the context of digitization is important both for the students and teachers to practice a modern teaching style that aims to develop their skills.

Nowadays our challenge is to use and build "effective technology- based system" that could help use to be more aware of how we think and behave (Gurteen, 1998). Moreover, "Information and communications technologies" are continuously changing our lives, and all human activities are transforming "the ways we do things at home, at work and in the larger society" (Hasan and Meloche, 2013).

\section{References}

Agabrian, M. (2008). Strategii de comunicare eficientă, Institutul European, Iași.

Augustsson, G. (2010), Web 2.0, pedagogical support for reflexive and emotional social interaction among Swedish students, Internet and Higher Education 13, pp. 197205.

Baban, E.G. (2015), Students' Innovative Behaviour in the Context of Knowledge Based Economy, The International Conference in Economics and Administration, ICEA-FAA 2015, June 5-6, pp.35-46.

Baeten, M., Kyndt, E., Struyven, K., Dochy, F. (2010), Using student-centred learning environments to stimulate deep approaches to learning: Factors encouraging or discouraging their effectiveness, Educational Research Review 5, pp. 243-260.

Bratianu, C. (2018). Intellectual capital research and practice: 7 myths and one golden rule. Management \& Marketing. Challenges for the Knowledge Society, 13(2), 859-879.

Bratianu, C. \& Bejinaru, R. (2017). Knowledge strategies for increasing IC of universities. In Lopez, I.T. \& Serrasqueiro, R. (Eds.). Proceedings of the 9th European Conference on Intellectual Capital, Instituto Universitario de Lisboa (ISCTE), (pp. 34-42), Portugal, 6-7 April 2017. Reading: Academic Conferences and Publishing International. 
Bratianu, C. \& Vatamanescu, E.M. (2017). Students' perception on developing conceptual generic skills for business: A knowledge-based approach. VINE Journal of Information and Knowledge Management Systems, 47(4), 490-505.

Ceobanu, C. (2016). Învățarea în mediul virtual: ghid de utilizare a calculatorului în educație, Editura Polirom, București.

Chaharbaghi, K., Newman, V.(1996),Innovating: towards an integrated learning model, Management Decision, Vol. 34 Iss 4 pp. 5 - 13.

Contu, E.G. (2017), The role of classical and modern teaching methods in business education, The 11th International Conference on Business Excellence, Strategy, Complexity and Energy in changing times, 30-31 March 2017, Bucharest, pp.87-88.

Contu, E.G. (2017), The Role of Intellectual Capital in Higher Education, 9th European Conference on Intellectual Capital, Instituto Universitário de Lisbon, Portugal, 6-7 Aprilie ,pp.66-70.

Gurteen, D., (1998),Knowledge, Creativity and Innovation, Journal of Knowledge Management, Vol. 2 ,Iss 1, pp. 5 - 13.

Hasan, H., Meloche, J. (2013), Innovative ICT-mediated activities for people, profit and planet, European Journal of Innovation Management, Vol. 16 No. 3, 2013, pp. 335354.

Iatagan, M. (2012). Strategii de finanțare a învățământului superior românesc în context european, Editura Universitară, București.

Kolb, A.Y, Kolb, D.A (2005), Learning Styles and Learning Spaces: Enhancing Experiential Learning in Higher Education, Academy of Management Learning \& Education, Vol. 4, No. 2, pp. 193-212.

Marginson, S. (2010), Higher Education in the Global Knowledge Economy, Procedia Social and Behavioral Sciences 2 , pp. 6962-6980.

Mayo, A. (2014). Valoarea umană a organizațiilor, Editura BMI, București.

Nicola, I. (1984). Pedagogie școlară, Editura didactică și pedagogică, București.

Pânișoară, I.O. (2008). Comunicarea eficientă. Ediția a III-a, revăzută și adăugită”, Editura Polirom, București.

Sit, J.W.H., , Chung, J. W.Y., Chow, M. C.M., Wong,T.K.S. (2005),Experiences of online learning: students' perspective, Nurse Education Today , 25, pp. 140-147.

Sorensen, E. K. (2007), Dialogic e-learning2learn: Creating global digital networks and educational knowledge building architectures across diversity, Multicultural Education \& Technology Journal, Vol. 1 Iss: 3 pp. 162 - 177.

Vrontis,D., Thrassou, A., Melanthiou, Y. (2007), A contemporary higher education studentchoice model for developed countries, Journal of Business Research 60, pp. 979-989. 